Norwich, Connecticut Clean Cities

\title{
Demonstration of Alternative Fuel, Light and Heavy Duty Vehicles In State and Municipal Fleets
}

Performed Under DOE/Conn OPM Grant DE-FG07-97ID13498

\author{
Final Report
}

Prepared by the Norwich Clean Cities Program

February 6, 2002

\author{
Peter Polubiatko, Norwich public Utilities \\ Electric Division Manager \\ Norwich Clean Cities Coordinator \\ John H. Kennedy \\ Kennedy Technical Services \\ Michael A. Tucchio, PhD \\ Creative Technologies, Inc.
}


Section 1: Purchase and place in service in light and heavy duty AFVs.
A. Background
3
B. Project Implementation
C. Summary and Conclusions

Section 2. AFV Student Environmental Education Project
A. Background 5
B. Project Implementation 5
1. Purpose 5
2. Classroom Instruction 5
3. Road Test and Demonstration
4. Student Reporting and Follow Up
5. Project Participants
C. Test Results and Data
1. General Description of Data and Test Records
2. Student Data Collection
b. EV Emissions Sheet
c. Gasoline and EV Comparison Sheet
D. Summary and Conclusion
Student Essays
Appendix A Environmental Education Materials / Norwich Public Schools / Middle Schools




\section{Section 1: PURCHASE AND PLACE IN SERVICE LIGHT AND HEAVY DUTY AFVS}

\section{A. Background}

In March of 1997, the City of Norwich Department of Public Utilities was awarded a $\$ 150,000$ grant toward the incremental cost of two school buses, one to be powered by compressed natural gas and the second by electric batteries. During the summer, Blue Bird, the bus supplier, notified Norwich that the drive train supplier for the electric bus was withdrawing from the market. Blue Bird's efforts to find an alternate supplier were unsuccessful and the suggestion was made that a second CNG-powered bus be substituted. Recognizing that the incremental costs for a second CNG bus would be less than the electric bus, the request for change of scope also included incremental costs to add two electric pick-up trucks. Following approval of this change, the second CNG school bus and two Ford Electric Rangers were ordered. The last component of the program consisted of a Middle School student educational program wherein students studied environmental pollution and observed and calculated how electric vehicles could minimize pollutants by comparing them to a conventionally powered vehicle. This change-of-scope was approved in the Fall of 2001 and is described in Section 2 of this report.

\section{B. Project Implementation}

The initial CNG bus was delivered in March of 1998 and, following Connecticut DMV certification, was used for a number of public outreach, educational activities and demonstrations during the Spring and Summer. It was placed in limited service with the Norwich School System in the Fall. The second CNG school bus was delivered to Norwich in the last quarter of 1998 and was outfitted with gas leakage sensing equipment. Also, the lease of the two Electric Rangers was executed in November with delivery planned for February 1999.

The second CNG school bus was placed in service with the Norwich Public School System early in 1999 and performed in an exemplary manner. Students, drivers and parents were all extremely positive on the quiet, smooth, non-polluting features of these buses. The two Electric Rangers, powered by nickel metal-hydride batteries, were delivered during the second quarter of 1999 and placed in routine service by NPU. Several test and demonstration runs were made to define operational characteristics and showcase them to the public. Initial problems related to battery charging and other electronic systems were encountered forcing their return to the dealer for corrective maintenance. Substantially increased operating range as compared with the lead-acid battery-powered Rangers was observed.

For the balance of 1999 and throughout 2000 and 2001, the CNG school buses performed very well in routine student transportation and for special events. The Electric Rangers have been less reliable and a number of electrical and thermal 
systems problems plus manufacturer recalls have resulted in considerable down time requiring return to the dealer for repairs and upgrade.

For both buses and electric trucks, NPU has continued to collect operational and maintenance data that has been forwarded to the designated agency for analysis and reporting.

C. Summary and Conclusions

The two CNG school buses procured under this program along with a third from a parallel program are fully integrated into the Norwich School transportation system. Although there is no clear fuel economy advantage, their clean, quiet operation and lower maintenance make them very attractive alternatives to diesel buses.

The Electric Ranger pick-up trucks have been disappointing primarily because of their limited availability due to maintenance problems. When they are available, the drivers are very satisfied and enjoy their clean, quiet operation with no noticeable difference from their gasoline counterparts relative to performance and comfort. 


\section{Section 2: AFV STUDENT ENVIRONMENTAL EDUCATION PROJECT}

A. Background

The final part of the grant program was to educate students of the Norwich School System on the advantages of the use of AFVs in reducing mobile emissions and the resulting environmental pollution. The education project would be accomplished in two ways:

1. Purchase environmental test equipment for use by students of middle schools and the high school.

2. Establish a project in a middle school wherein the science students would observe and calculate the difference in pollution between a gasoline and a battery-powered electric truck by way of an over-the-road test demonstration.

B. Project Description

1. Purpose

The purpose of this program was to increase the awareness of students in the Norwich School System of the environmental pollutants resulting from the use of conventionally fueled vehicles and to demonstrate how the use of certain types of AFVs can mitigate these pollutants. The initial activity under this project was to purchase environmental test and analysis equipment for use by middle and high school students. This is described in Appendix A. The other major activity was to plan and carry out a classroom and on-road test project to enable students to understand and experience first hand the difference in emissions resulting from operation of a gasoline powered pick-up truck and a similar truck powered by electricity.

2. Classroom Instruction

An initial instruction period of about one hour was conducted in the Kelly Middle School classroom of science teacher Peter Popinchalk. Mr. Popinchalk had selected 14 of his science students, all volunteers, to participate. The participating students were as follows: 
The instruction period consisted of overhead charts and diagrams discussing the general subject of environmental pollutants resulting from the operation of transportation vehicles and the degree of energy dependence on foreign oil sources. This was followed by a presentation on the basics of electric vehicles and the advantages and disadvantages of their use in daily transportation. Finally, a summary of the project in which they were to participate was given.

\section{Road Test and Demonstration}

One of the Ford Electric Ranger pickup trucks from the fleet of Norwich Public Utilities was used for the reference test vehicle. A test route of 8.3 miles involving various types of terrain and urban/suburban driving was selected and a dry run made to establish reference data. Test runs on two separate days were planned with the students divided into two groups with data sheets and clipboards. A van was provided by SCORE, School and Community Outreach Excellence, to transport the students which followed the electric truck and permitting them to record data. Details of data recording appear in the following section of this report. Prior to each data run, each student was taken for a brief drive on the school grounds to familiarize them with the unique features of an electric vehicle.

\section{Student Reporting and Follow Up}

Following each run it was planned that the students would return to the classroom for guidance in completing calculations and understanding the importance of the comparative results of environmental pollution between gasoline and electric powered trucks. Once all calculations are complete, the students are to prepare brief, written essays on the project and to discuss with the instructor and the science teacher what they have learned from the project. As a follow-up project, the participating students will be encouraged to participate in the 2002 Junior Solar Sprints, a program active at Kelly Middle School for the past three years, Norwich, Connecticut Clean Cities

\section{Project Participants}

The following individuals participated in the planning and implementation of this program:

Peter Polubiatko - Norwich Clean Cities Coordinator

Patricia Grondin - Science Coordinator, Norwich Public Schools

Peter Popinchalk - Science Teacher, Kelly Middle School

Thomas Giard - Director, SCORE

John Kennedy -Kennedy Technical Services

Michael Tucchio, PhD -Creative Technologies, Inc. 
C. Test Results and Data

1. General Description of Data and Test Records:

The purpose of the program is to ask middle school students to participate in a program to compare the emissions from a Ford Ranger EV pickup truck to a conventional gasoline Ford Ranger pickup truck. No actual emissions were measured as that is well beyond the scope of the current project. The emission data is based upon the Environmental Protection Agency, EPA, Greet 1.5a program ${ }^{1}$ and the Electric Power Research Institute, EPRI, published data ${ }^{2}$. Figure 1 was taken after familiarizing the students with the EV Ford Ranger.

Gasoline Ford Ranger: The conventional Ford Ranger has an EPA gasoline fuel economy rating of about 22 miles per gallon (MPG). This fits very well within the EPA Greet 1.5a parameters for a 22.4 MPG gasoline vehicle. The EPA mobile

\footnotetext{
${ }^{1}$ EPA Greet 1.5a Version April 21, 2002, Michael Wang

2

EPRI Repart TB-101827, Apr 1993 Electric Vehicles and Clean Air
} 
emission data is shown in Table 1. EPRI data is used for the Hydrocarbons and Carbon Dioxide as indicated in the table.

Table 1

$\begin{aligned} & \text { Per-Mile Fuel Consumption and Emissions of Vehicle Operations: Near-Term } \\
& \text { Technologies }\end{aligned}$
\begin{tabular}{|l|c|c|}
\hline $\begin{array}{l}\text { MPG (conventional gasoline equivalent } \\
\text { gallon) }\end{array}$ & $\begin{array}{l}\text { Baseline Conventional } \\
\text { Gasoline Vehicle }\end{array}$ & $\begin{array}{l}\text { Electric } \\
\text { Vehicle }\end{array}$ \\
\hline Fuel consumption (Btu/mile) & 22.4 & 67.2 \\
\hline Fossil fuel use (Btu/mile) & 5,156 & 1,719 \\
\hline Petroleum use (Btu/mile) & 5,156 & 0 \\
\hline Emissions: grams/mile & 5,073 & 0 \\
\hline VOC: exhaust & & 0 \\
\hline VOC: evaporation & 0.08 & 0 \\
\hline CO & 0.127 & 0 \\
\hline Nox & 5.517 & 0 \\
\hline PM10: exhaust & 0.275 & 0 \\
\hline PM10: brake and tirewear & 0.012 & 0.021 \\
\hline Sox & 0.021 & 0 \\
\hline CH4 & 0.05 & 0 \\
\hline N2O & 0.084 & 0 \\
\hline CO2 & 0.028 & 390 \\
\hline
\end{tabular}

Electric Ford Ranger: Electric Vehicle emissions come from two sources, the vehicle itself and the electric power generation station. The EV emissions data from the EPA Greet 1.5a program, supplemented by the EPRI data, is also shown in Table 1. Table 2 combines the data from EPA Greet 1.5a model and EPRI to obtain an emission parameters in the column labeled EV Grams/KWhr, that can be used with the student's data sheets. This is an intermediate table that was not supplied to the students. 
Table 2

Gasoline and Electric Vehicle Emissions on a Grams per Mile and Grams per KWhr basis

\begin{tabular}{|l|r|r|r|}
\hline & $\begin{array}{l}\text { Conventional } \\
\text { Gasoline } \\
\text { Pickup Truck }\end{array}$ & $\begin{array}{l}\text { Electric } \\
\text { Vehicle* }\end{array}$ & $\begin{array}{l}\text { EV Grams/ } \\
\mathrm{kWh}\end{array}$ \\
\hline Fuel consumption (KWhr/mile) & & 0.50381 & \\
\hline Emissions: grams/mile & gms / mile & gms/mile & gms/KWH \\
\hline VOC: exhaust & 0.08 & 0.0004 & 0.00063 \\
\hline VOC: evaporation & 0.127 & 0.0000 & 0.0000 \\
\hline CO (EPRl used for EV) & 5.517 & 0.0221 & 0.0439 \\
\hline Nox (EPRl used for EV) & 0.275 & 0.0165 & 0.0328 \\
\hline PM10: exhaust & 0.012 & 0.0007 & 0.0014 \\
\hline $\begin{array}{c}\text { PM10: brake and tirewear (at } \\
\text { the vehicle) }\end{array}$ & 0.021 & 0.0210 & 0.0417 \\
\hline Sox & 0.05 & 0.0019 & 0.004 \\
\hline CH4 (EPRI data used for EV) & 0.084 & 0.0002 & 0.00034 \\
\hline CO2 (EPRl used for EV) & 390 & 46.80 & 110.88 \\
\hline
\end{tabular}

$(1 \mathrm{KWhr}=3412 \mathrm{BTU})$

Except as noted, emissions for the EV are from the Power Plant.

2. Student Data Collection:

The data sheet for the students was broken into three parts to ease the understanding of the computations:

a) EV Route Sheet

b) EV Emissions Sheet

c) Gasoline and EV Comparison Sheet

\section{a. EV Route Sheet}

Rather than use typical emissions per mile for an EV, the student were required to calculate the amount of energy used by the EV in a test loop of varying terrain of approximately 8-9 miles. In this manner. the students obtained a more comprehensive understanding of the importance of energy concepts using the power requirements of an EV as an illustration. Based upon the experience of the advisors, a table of energyuse factors versus terrain was constructed for the students. This is incorporated into the EV Route Sheet for the students. Table 3 shows this concept and with data entries listed. The energy factors provide a subjective decision for each student, e.g. the difficulty of terrain. (Not all final calculations would be identical to one another.) It also provided a good amount of discussion and interaction for the advisor and students as 
they rode in the school van and followed the EV. Figure 2 depicts a student with her EV Route sheet. 
TABLE 3

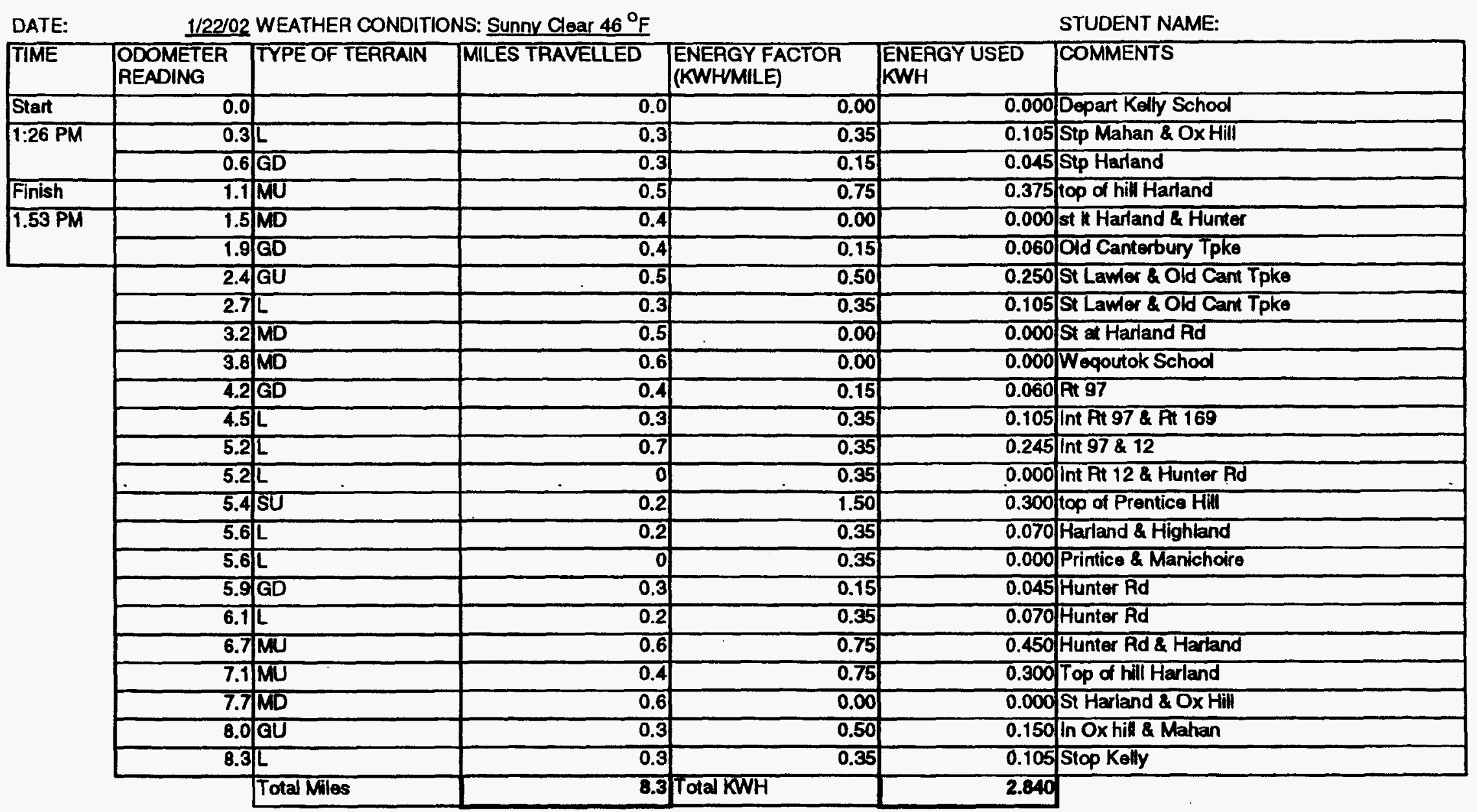

\begin{tabular}{|l|r|}
\hline Torrain Types and Energy Factors & 0.35 \\
\hline LLovel & 0.5 \\
\hline GU Gradual Uphill & 0.75 \\
\hline MU Moderate Uphill & 1.5 \\
\hline SU Stoep Uphill & 0.15 \\
\hline GD Gradual Downhill & 0 \\
\hline MD Moderate Downhill & 0 \\
\hline SO Stoep Downhill & 0 \\
\hline
\end{tabular}


b. EV Emissions Sheet : The emissions in Grams per KWhr for the EV are combined on table 4 for each of the emission constituents. The entries reflect the student data from Table 3.

Table 4

Emisslons from the EV and Power Plant

\begin{tabular}{|c|l|l|r|r|}
\hline Type of Power Plant & \multicolumn{1}{|c|}{ Explanation } & $\begin{array}{l}\text { Total Emissions } \\
\text { from EV and Power } \\
\text { Plant } \\
\text { Grams /KWH }\end{array}$ & Total KWH Used & Emissions \\
\hline VOC: exhaust & $\begin{array}{l}\text { VOC=Volatile Organic } \\
\text { Compounds from tailpipe }\end{array}$ & 0.00063 & $\begin{array}{c}\text { Grams } \\
\text { (See Note) }\end{array}$ \\
\hline VOC: evaporation & $\begin{array}{l}\text { VOC=Volatile Organic } \\
\text { Compounds from } \\
\text { evaporating sources }\end{array}$ & 0.0017892 \\
\hline CO & Carbon Monoxide & 2.84 & 0.84 \\
\hline NOx & Nitrous Oxide & 0.0439 & 2.84 & 0.124676 \\
\hline PM10: exhaust & $\begin{array}{l}\text { Particulate Material, 10 } \\
\text { Microns from tailpipe }\end{array}$ & 0.0328 & 2.84 & 0.093152 \\
\hline PM10: brake and & $\begin{array}{l}\text { Particulate Material, 10 } \\
\text { Microns from wearing } \\
\text { surfaces }\end{array}$ & 0.0014 & 0.003976 \\
tirewear & Oxides of Sulfur & 0.0417 & 2.84 & 0.118428 \\
\hline SOx & Unburned Hydrocarbons & 0.004 & 2.84 & 0.01136 \\
\hline CH4 & Carbon Dioxide & 110.88 & 2.84 & 0.0009656 \\
\hline CO2 & & & 2.84 & 314.8992 \\
\hline
\end{tabular}

Example:

If the energy used is $2.5 \mathrm{KWH}$, the NOx emission from the truck is: $2.5 \times 0.0328=0.082$ Grams

Units: (KWH). (NOx grams emissions/ KWH) = grams NOX

Note: The total emissions in grams from the final column will be transferred to the "Electric Truck Emissions Grams column in the next data sheet. 
c. Gasoline and EV Comparison Sheet. Table 5 is essentially the results of the student's efforts and compares the emission characteristics of the EV and a similar gasoline powered vehicle.

\begin{tabular}{|c|c|c|c|c|c|c|c|}
\hline \multicolumn{5}{|c|}{$\begin{array}{l}\text { Gasoline Pickup Truck - Ford Ranger, Fuel Economy, } 22 \\
\text { Miles/Gallon }\end{array}$} & \multicolumn{2}{|c|}{ Electric Truck } & \multirow{2}{*}{\begin{tabular}{|l|} 
Comparis \\
on \\
EV \\
emissions \\
as a \% of \\
Gasoline \\
\end{tabular}} \\
\hline Emission type & Explanation & $\begin{array}{l}\text { Emission } \\
\text { s: } \\
\text { grams/mil } \\
e\end{array}$ & $\begin{array}{l}\text { miles } \\
\text { travelle } \\
d\end{array}$ & $\begin{array}{l}\text { Emission } \\
\text { s, Grams }\end{array}$ & $\begin{array}{l}\text { Emission } \\
\text { s Grams }\end{array}$ & $\begin{array}{l}\text { Differenc } \\
\text { e Grams }\end{array}$ & \\
\hline $\begin{array}{l}\text { VOC: exhaust from } \\
\text { tailpipe }\end{array}$ & $\begin{array}{l}\text { VOC=Volatile Organic } \\
\text { Compounds from tailpipe }\end{array}$ & 0.08 & 8.3 & $\overline{0.664}$ & 0.0018 & 0.6622 & 0.2695 \\
\hline VOC: evaporation & $\begin{array}{l}\text { VOC=Volatile Organic } \\
\text { Compounds from } \\
\text { evaporating sources }\end{array}$ & 0.127 & $\overline{8.3}$ & 1.0541 & 0.0000 & 1.0541 & 0.0000 \\
\hline $\mathrm{CO}$ & Carbon Monoxide & 5.517 & 8.3 & 45.7911 & 0.1247 & 45.6664 & 0.2723 \\
\hline NOx & Nitrous Oxide & 0.275 & 8.3 & 2.2825 & 0.0932 & 2.1893 & 4.0811 \\
\hline $\begin{array}{l}\text { PM10: exhaust from } \\
\text { tailpipe }\end{array}$ & $\begin{array}{l}\text { Particulate Material, } 10 \\
\text { Microns from tailpipe }\end{array}$ & 0.012 & $\overline{8.3}$ & 0.0996 & 0.0040 & 0.0956 & 3.9920 \\
\hline $\begin{array}{l}\text { PM10: brake and } \\
\text { tirewear }\end{array}$ & $\begin{array}{l}\text { Particulate Material, } 10 \\
\text { Microns from wearing } \\
\text { surfaces }\end{array}$ & 0.021 & $\overline{8.3}$ & 0.1743 & 0.1184 & 0.0559 & 67.9449 \\
\hline SOx & Oxides of Sulfur & 0.05 & 8.3 & 0.415 & 0.0114 & 0.4036 & 2.7373 \\
\hline $\mathrm{CH} 4$ & Unburned Hydrocarbons & 0.084 & 8.3 & 0.6972 & 0.0010 & 0.6962 & 0.1385 \\
\hline $\mathrm{CO} 2$ & Carbon Dioxide & 390 & 8.3 & 3237 & 314.8992 & 2922.100 & 9.7281 \\
\hline
\end{tabular}


Example: To calculate the NOx emission from the gasoline truck:

if the distance travelled $=9.2$ miles, the NOx emission from the truck is:

2.53 grams

$9.2 \times 0.275=$

Unit equation: (Miles).(NOx grams

emissions $/ \mathrm{mile})=$

grams

NOx

Example: To calculate the \% difference use the

following logic

$\%$ Difference $=$ Emissions EV Grams/Emissions Gasoline Grams for each emission

type $\times 100$

Where Greet $1.5 a$ is not used EPRI data is substituted 


\section{Summary and Conclusions}

This educational project was implemented precisely as planned and appeared to generate the hoped-for interest and enthusiasm of the eighth grade students. The student essays are included in their entirety below because it shows their level of understanding, concerns and insights into their future.

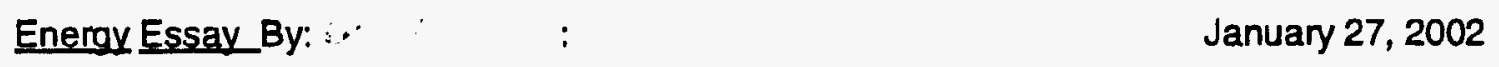

This project and field study has made me realize how polluting some cars are and how much more efficient electric vehicles can be. It has also made me realize the importance of finding new, cleaner, and more efficient energy sources for our power stations and vehicies. I leamed about all the things gasoline powered vehicles put into the atmosphere and how it is damaging the planet and the many advantages electric vehicles have, seeing as how their power comes from a power plant with more efficient pollutant scrubbers. I also plan to participate in the solar sprint program, which involves building a solar powered electric car, which may help come up with a solution for a cleaner altemative energy source to fossil fuels in cars. However, we must find an altemative energy source whether it be hydrogen, solar, or another so that we can help our planet by lesser pollution. I am not one of Those environmentalist freaks who think no or little energy and other environmentally harming activities should be stopped, but I do care about the planet and wish to make it and its resources last for a longer time.

About two months ago my friend told me that my Science teacher. Mr. Popinchalk was doing an energy saving project with a few of the eighth graders. I decided to join this activity because it seemed interesting and fun to do.

A week later we met two very Interesting men with a lot of experience and knowledge about electricity and it's uses. They told us that this project was about helping everyone by decreasing pollution by getting people to use electrically powered vehicles and leaming about them.

A few days have passed and we all got to ride in an electrically powered truck. Have you ever been in one? If you haven't let me tell you what's different. 'Right away you can notice that this car doesn't make any sound because they're is no engine. There is no exhaust pipe, so it doesn't pollute the air. It has many advantages. It only uses energy when you push the gas 
pedal, It uses no energy when you are not moving and it even gains energy when you drive downhill. It is perfect for cities, because you do not use energy when you are stuck in traffic and there is no engine to overheat.

Doesn't this sound like a wonder car? Yes it does, but it is not perfect. These electrically powered vehicles cost twice as much as the same vehicle in that runs on gasoline. Its energy also reloads for a long time and it is not superior for long trips. It is a lot cleaner though. It gets its energy from a power plant and if the power plant uses hydroelectricity the electrically powered vehicle uses no energy at all. An ordinary car gets its energy from a power plant that burns fossil fuels which pollutes the earth and then the gasoline is bumed again in the car so we pollute our planet twicel (?) ${ }^{3}$

This program can help us a great deal I am extremely happy about being a part of this awesome plan. I know that we well help reduce pollution and help our planet. We are making history here! This is a great opportunity for young people like myself to leam about helping the environment.

The Clean Cities Program is a fun and educational experience. I am very happy that I joined because I have leamed a lot that I probably wouldn't have known if I didn't participate. For example, I leamed that there are electric powered vehicles that get their energy from power plants, These electric powered vehicles have no tailpipe because they don't have exhaust. They run on a battery that is recharged at the power plant. These electric powered vehicles are not only much quieter than cars that run on gasoline, but they are much more environmentally friendly. Cars that run on gasoline emit harmful gasses into the atmosphere that can cause health problems. By using electric powered vehicles, we wouldn't have to worry about this.

As a part of the Clean Cities Program, we participated in a field study. During the field study, students rode in a gasoline-powered van. We followed the electric powered truck on a few local roads. Every so often, Mr.Kennedy would stick his hand out the truck window. We would take down data such as how many miles we had traveled and what type of terrain we were driving on. Using that information, we did a lot of math and figured out that the electric vehicle emitted almost nothing compared to the gasoline powered vehicle.

As you can see, the Clean Cities Program teaches students a lot about gasoline powered vehicles compared to electric powered vehicles and the difference between the two. Thanks to Mr.Tucchio and Mr.Kennedy I now have a different perspective on vehicles. After 
participating in this program, a different thought crosses my mind as I drive down the street that had never before- how many of the harmful gasses coming from the tailpipe could be reduced or even dlsplaced completely by driving an electric powered vehicle?

This program really sumprised me. I thought that we would just leam some numbers and not have a clue what any of them were or what they meant. What we actually did was leam about what an electric truck used for fuel, how it used its energy, and a lot about how much pollutants both electric, and gasoline trucks produce. We leamed about how some of these electric vehicles can produce energy when they go downhill. With these vehicles we would be able to cut back on the use of the little bit of fossil fuels that we have. I think that this program was very informative and should be taught at more schools so other kids could share this knowledge.

This program is one of the most informative things l've ever done. We have leamed many knew things about pollution. For instance did you know that if you were to run in a race and before the race you had a team meeting in the parking lot behind a bus you would have a much less chance of winning the race. You would probably lose the race because of carbon dioxide. Carbon dioxide (monoxide) ${ }^{4}$ is a gas that replaces oxygen in your body, and oxygen helps you run faster. The most important thing we leamed about in this program was the importance of altemative energy sources. For example it would be much less polluting if people started to drive electric vehicles instead of gasoline powered vehicles. In our program we got the privilege to take a short ride in an electric truck. It performed just as well as a gasoline powered vehicle. The only difference is that the electric vehicle put a lot less pollution into our atmosphere. Also we did a field study in which we drove in a bus behind the electric vehicle. We took many tests and came to the solution that the electric truck can perform just as well if not better than any truck on the market.

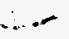

$1 / 29 / 02$

In this experience of solar sprint I leamed that you can save a lot of pollution by using battery powered cars. I have leamed about all types of pollution in science and this solar sprint

\footnotetext{
Question by advisor

Camment in brackets by advisar
} 
experience has helped me leam and take a better understanding about cars and how much they pollute. I was taught to take down data and to use it in a constructive way.

I had a good time going out on trips with the battery powered car. We leamed how the car works, and about all the gauges to tell you what is going on, and if the car is using battery power or gaining battery power.

It was nice to know how much the cars are polluting and how much energy the battery powered cars are saving. Also how the battery powered cars are quieter then gasoline operated cars which cuts down on noise pollution. If we all had a battery powered car we could make a difference in the worlds pollution problem.

I liked talking part in this activity it was great and educational.

Alternative Fuel Vehicles - Electric-powered Automobiles

Did you know that gasoline vehicles are almost one and a half times as pollutant as electric vehicles? Did you know that gasoline powered cars account for about a quarter of the greenhouse gases? In the U.S. and other countries, these issues must be addressed or we may be faced with intolerable health, political, and economic costs. Since vehicle usage continues to boost, oil prices will most likely not linger at their current low level. The most efficient and substantial option that remains is the introduction of altemative fuel vehicles.

Electric powered vehicles are the main focal of the Clean Cities initiative Program. After following an electric truck in a gasoline powered vehicle, we were able to prove that electric vehicles without a doubt are more efficient than automobiles that are powered by gas.

We did this by figuring out the miles we traveled, how much energy we used, the slope of the land, etc. Eventually, we got to how much pollution we emitted into the air. We discovered that gasoline powered vehicles release much more harmful emissions into the atmosphere. Even though power plants discharge detrimental gases as well, when charging the electric vehicles our survey proved them still more proficient. These types of cars would practically rid carbon monoxide emissions and significantly reduce nitrogen oxide secretions.

Thus, these are the kinds of vehicles that may be in our future, so I strongly feel that we should have more programs such as this one to teach people about the damage that we are doing to our environment due to gas powered cars and what we can do about it such, as altemative energy sources, including electric-powered automobiles.

Clean Cities Initiative -

1/29/02

From the Clean Cities Initiative program, I have leamed how car pollutants harm the 
environment and how we can help this problem with the use of electric vehicles.

During this two day procedure we followed around the electric truck, taking measurements that we later calculated into figures that we compared with electric vehicles. We even got to ride in the electric truck! The truck looked almost exactly the same as a gasoline truck. Besides the difference in the engines, I wouldn't be able to tell them apart.

When we got back to the school, and did a little math, we realized how cleaner and better for the environment electric vehicles are. The figures where amazing. Gasoline cars look like pollution giants compared to electric.

Now that I have been through this program, I can hardly wait to tum 16 and get an electric vehicle of my own. Besides the fact that it cuts down on pollutants, it doesn't make any loud engine noises like gasoline vehicles dol

I have leamed many interesting facts from participating in the Clean Cities program. In that program, we followed an electric powered vehicle and gained information on how much pollution it produced versus a gasoline powered vehicle. We found that the electric powered vehicle produced less pollution than a gasoline powered vehicle. This corresponded with what we leamed in science. A gasoline powered vehicle is one of the heaviest polluters. I enjoyed participating in the Clean Citles Program and am interested in leaming how we can help to improve pollution in our community.

I have enjoyed participating in the Clean Cities program very much within the past few weeks. I have leamed many things from the off site experiments, the visits from Mr. Kennedy and Mr. Tucchio and being able to experience the emisslons from the car.

The experiment that we did was to drive around in a gasoline powered van, and take data on the vehicle ahead of us which was an electric powered pickup truck. I leamed that in an electric powered car, it gives off no exhaust, so it doesn't pollute, it is much quieter than the normal cars that we drive, and you don't always need to keep your feet on the pedals because you can coast, which means that you are not using any energy.

The visits from Mr. Kennedy and Mr. Tucchio were very helpful in our research. They helped us to fill out evaluation sheets, spoke to us before we started, and then came along with us during our process. 
This helped me because now I know what is the difference between an electric and gasoline powered car. Also I found out how much of a pollutant the cars are that we drive every day.

Thank you

Participating in the Clean Cltles Initiative program was not only educational, interesting, and enjoyable, but it will certainly become one of the highlights of my yearl I have leamed so much I thought the information was going to start to spill out of my ears! To begin with, were you aware electric cars don't pollute nearly as much as gasoline powered cars, which most of us are driving? After following an electric truck, observing, collecting, and figuring data, I gained the knowledge the electric car certainly released much fewer pollutants into the air around us. This helps our environment in more than one way! Furthermore, by being a part of the Clean Cities program, I was taught so much about the energy efficient cars thanks to Mr. Kennedy and Mr. Tucchio. These great vehicles are not only incredibly quiet, but don't release any exhaust from tailpipes since they don't have one. One thing I found extremely interesting was when coasting down a hill, and your foot is not on the pedal, no energy is being used. In conclusion, the Clean Cities Initiative program taught me so much about these energy-efficient cars, and made me feel as if I was part of a real program that will make a difference in our world. Now I know when I grow up, I want an electric powered car to help our environment!

As is evidenced by their essays, all the participants appreciated a realization of the advantages of alternative fuel vehicles, particularly battery-powered electric vehicles, in reducing the amount of harmful emissions. It also shows they are keenly aware of their environment and their future. The project demonstrated that a hands-on experience engendered stronger interest and involvement by the students than merely classroom lectures although it was Important to introduce the concepts there prior to the field experience. Kelly Middle School, with the guidance of Mr. Popinchalk, has been a leader in the local school system in encouraging greater awareness of the environmental issues associated with mobile source emissions particularly through dedicated science teachers and curriculum staff. This has been demonstrated by the number of students entering solar car models in the Junior Solar Sprints Program. Last year, for instance, Kelly teams took the first 5 places (out of 30 plus entries) in the speed event at the State of Connecticut competition. A number of students participating in this project have indicated their intention to build and race solar car models in the 2002 Junior Solar Sprints. 
It is a strong conclusion of those of us who planned and conducted this program that similar projects, conducted in other middle schools in this and other regions would have a very positive impact on awareness of the environmental problems related to transportation sector emissions and the place AFVs play in their mitigation. We strongly encourage that this or similar programs be considered for the future. 


\section{Appendix A}

\section{Environmental Education Materials / Norwich Public Schools / Middle Schools}

The Norwich Public School District has been an active member in the Norwich Clean Cities State Energy Program since its inception. Environmental issues and an awareness of the impact of air and water pollution have become an increasingly important focus of study in our middle schools. Initiatives introducing alternative fuel vehicles to local fleets and the potential AFV's offer in lessening pollution and lowering dependence on foreign oil, are issues that have become integrated in student environmental studies. Educational materials provided by DOE/Conn OPM funding have been used to introduce these environmental issues in district eighth grade science classes. Equipment acquired has been used by students in conducting local field studies on both air and water quality. Student interest in environmental issues has led to the organization of Enrichment Clubs in both middle schools. More in depth local hydrology studies, which included the submission of water sampling data to the international GLOBE Program via the Internet, were conducted by students at Teachers' Memorial Middle School. Student participants developed a PowerPoint presentation highlighting their research, which was shared with middle school classes as a culminating activity. Kelly Middle School students' project work and club activities reflected their interest in AFV's. Student enthusiasm in conducting research in the Electric Vehicle Project and their most successful participation in the State Junior Solar Sprint Competitions, are indicators of the impact that education involving "real-world" issues garners among students, the future leaders of our communities. Generous DOE/Conn OPM funding has afforded the district the opportunity to bring the study of these critical environmental issues and the ensuing projects into the classroom.

\section{Environmental Education Materials / Norwich Public Schools / Norwich Free Academy}

The Clean Cities Program in the City of Norwich has assisted the Norwich Free Academy in two specific disciplines. First, was the partnership between the Clean Cities Coalition and the NFA journalism students. The students produced a video that discussed the benefits of using natural gas powered school buses. This video was used for instructional purposes in the community and with parent groups at the elementary schools as well as being aired on the local cable access channel.

The science department received a substantial number of probes to be used in monitoring air quality for instructional purposes. The students used the materials purchased through the grant monies to test for oxygen, carbon monoxide, sulfuric acid, chlorine gas, ozone and carbon dioxide.

The relationship between the schools and the Norwich Clean Cities Coalition allows the schools to ensure that environmental education will be an active component of the current curriculum. 